Boise State University

ScholarWorks

$3-1-2013$

\title{
Troubled Consciences: New Understandings and Performances of Penance Among Catholics in Protestant England
}

Lisa McClain

Boise State University 


\title{
Troubled Consciences: New Understandings and Performances of Penance Among Catholics in Protestant England
}

\author{
LiSA MCCLAIN
}

Prior to Protestant reforms of the sixteenth and seventeenth centuries, Catholic clerics frequently preached about the necessity of confessing one's sins to a priest through the sacrament of penance. After the passage of laws in the 1570s making it a criminal offense to be a Catholic priest in England, Catholics residing in Protestant England possessed limited opportunities to make confession to a priest. Many laypersons feared for their souls. This article examines literature written by English Catholic clerics to comfort such laypersons. These authors re-interpreted traditional Catholic understandings of how sacramental penance delivers grace to allow English Catholics to confess when priests were not present. These authors-clerics themselves-used the printed word to stand in for the usual parish priest to whom a Catholic would confess. They legitimized their efforts by appealing to the church's modus operandi of allowing alternative means to receive grace in cases of extreme emergency. Although suggestions to confess without a priest's mediation sound similar to Protestant views on penitence, these authors' prescriptions differ from Lutheran, Calvinist, Anglican, and post-Tridentine Catholic positions on penance in the Reformation era. Diverse understandings of penitence lay at the heart of confessional divisions, and this article sheds new light on heretofore unexamined English Catholic contributions to these debates, broadening scholars' conceptions of what it meant to be Catholic in Reformation England and Europe.

\section{FTER the execution of Charles I in 1649, an English Catholic layperson 1 raised a pen and a voice to God, pleading:}

Oh hear me for thy Son Jesus's sake. That it may please thee to comfort and raise up those weak and dejected spirits which are ready to sink under the Burden of a Troubled or an Affrighted Conscience; that as thou hast showed them their sins and the punishments due for them; so thou wouldst show them their Savior and by directing them to lay hold upon his Cross, keep them from a final and everlasting shipwreck.

The author would like to thank the members of the Group for Early Modern Studies at Boise State University - Mac Test, Matthew Hansen, Steven Crowley, Janice Neri, and Jim Stockton-for their valuable suggestions during the writing of this article.

Lisa McClain is an Associate Professor of History at Boise State University. 
Oh hear me for thy Son Jesus's sake. That it may please thee to hear the Groans and Cries of all that are afflicted either outwardly or inwardly in Body or Soul: especially such who being oppressed for conscience sake have no place to fly unto nor no man careth for their souls. ${ }^{1}$

The anonymous writer of this prayer exhibited many of the greatest anxieties of English Catholics living under Protestant rule in Tudor-Stuart England. ${ }^{2}$ In 1559 , Elizabeth I's Act of Uniformity effectively abolished the Mass, prohibited the ordination of any more Catholic priests, and established Protestantism as England's only legal religion. In the century following the Act, English Catholics witnessed the disappearance of many sacraments, rituals, material objects, and places of worship central to their faith. With the advent of the penal laws in the 1570 s that made it a crime even to be a priest within England's borders, the number of Catholic priests and access to the sacraments gradually declined. ${ }^{3}$ Without regular access to priests - or as the prayer's author phrased it, "no man careth for their souls"-Catholics feared for their salvation. Many such Catholics worried over the weight of their sins, ready to "sink under the Burden of a Troubled or an Affrighted Conscience." After the Catholic Church heavily advertised its traditional remedy for such fears-the sacrament of penance - to laypeople for over a century in late medieval and, later, in Marian England, priests were now frequently unavailable to perform this sacrament so that laypersons could obtain forgiveness for their sins. ${ }^{4}$ This

\footnotetext{
${ }^{1}$ British Library (hereafter BL), Sloane MS 4035, f. 12.

${ }^{2} 1$ Eliz I, c. 2. This law sought to reverse the impacts of attempts to reestablish the institutional and sacramental teachings and structures of the Roman Church along the Tridentine model under Mary I. See Eamon Duffy, Fires of Faith (New Haven: Yale University Press, 2009).

${ }^{3}$ From 1571 to the end of her reign, Elizabeth I issued increasingly restrictive penal laws against Catholic practices. The severity of the laws and the rigor with which authorities enforced them fluctuated depending on the government's perceived threat of domestic uprising or foreign invasion, particularly by Spain. Practices prohibited include reconciling subjects to the Catholic faith, harboring priests, importing or possessing sacramental items such as rosaries and agni dei, and celebrating or hearing Mass. Punishments included loss of goods, imprisonment, and execution for treason. By the mid 1580s, a Catholic priest ordained after 1559 risked death if found within England. Fines for non-attendance at Protestant services grew significantly, and eventually the government could seize two-thirds of the income from the property of recusants who refused to pay fines for non-attendance. By the 1590s, the government required bonds of Catholics, and Catholic movements were restricted to within five miles of their homes. The most notable of these laws include 13 Eliz I, c. 1 and 2 (Act of Persuasions); 23 Eliz I, c. 1; 27 Eliz 1, c. 2; 29 Eliz I, c. 6; and 35 Eliz I, c. 2. James I and Charles I reissued the Elizabethan penal laws along with their own modifications. For examples, see 3 and 4 James I, c. 6; 7 James I, c. 6; Calendar of State Papers Domestic (hereafter referred to as CSP Dom) 16/5/41. See discussion of these issues in Lisa McClain, Lest We Be Damned: Practical Innovation and Lived Experience among Catholics in Protestant England, 1559-1642 (New York: Routledge, 2004), $19-37$.

${ }^{4}$ On pervasiveness of the penitential message and the necessity of the priesthood in providing sacramental penance, see Anne Thayer, Penitence, Preaching and the Coming of the Reformation, St. Andrews Studies in Reformation History (Aldershot, U.K.: Ashgate, 2002), esp. chapters 1 and 3; Eamon Duffy, The Stripping of the Altars, Traditional Religion in
} 
situation was particularly acute for Catholics below noble or gentry rank. The Protestant Church of England hoped the dearth of Catholic priests and sacraments would hasten the country's conversion to Protestantism. Catholic Church officials worried the Church of England was right. ${ }^{5}$

Faced with limited access to priests, how might English Catholics have re-conceptualized their understanding and performance of traditional sacraments? How could clerical and lay roles in these sacraments have been transformed in an effort to comfort Catholic laity without regular access to priests over the fate of their souls while still remaining orthodox? This article addresses such issues by looking at English Catholic re-interpretations of a particular sacrament - the sacrament of penance - in the century after Elizabethan reform. I examine literature published for English Catholic laypersons by English Catholic clerics in pastoral efforts to minister to believers they would likely never see. Such authors advised Catholics how to confess and receive absolution without a priest, a suggestion that would seemingly violate Catholic doctrine and perhaps sounds suspiciously akin to a "priesthood of all believers." To advocate such an opportunity, the authors of such works evinced a remarkable degree of practicality and a willingness to stretch the functions of the sacrament of penance rather than display strict adherence to the institutional form. They legitimized their efforts by appealing to the church's modus operandi of allowing alternative means to receive saving grace in cases of extreme emergency, all while remaining firmly within the orthodoxy of the Roman Church.

Some English Catholic authors began counseling those who struggled under the "Burden of a Troubled or an Affrighted Conscience" to construct oneon-one relationships with God so that they might examine their consciences, confess directly to God, judge themselves, receive absolution from God, and perform self-imposed penance. Examinations of conscience were not new, but these authors now emphasized them instead of the traditional confession to and absolution by a priest in sacramental confession. Self-judgment and self-imposition of penance were new. A priest traditionally judged and absolved the penitent and ordered penance so the penitent could atone for any sins. These authors - clerics themselves - stepped into the void created by the frequent physical absence of priests in England. They advocated that

England 1400-1580 (New Haven: Yale University Press, 1992), 54, 58-62, 315-16; W. David Myers, 'Poor Sinning Folk': Confession and Conscience in Counter-Reformation Germany (Ithaca, N.Y.: Cornell University Press, 1996); Thomas N. Tentler, Sin and Confession on the Eve of the Reformation (Princeton, N.J.: Princeton University Press, 1977).

${ }^{5}$ For example, see letter of Robert Southwell to Claudio Aquaviva, December 1586, in Unpublished Documents Relating to the English Martyrs, vol. 1, 1584-1603, ed. J. H. Pollen (London: Catholic Record Society, V, 1908), 313-14. 
laypersons confess directly to God, open themselves to God's will, and impose judgment and penance upon themselves accordingly. God would reward such efforts and purify the souls of the penitents. Authors assured readers of this in language strikingly similar to wording used to describe the benefits of sacramental penance. English Catholics were asked to alter traditional understandings of penance. They were asked to perform this new knowledge not in the public space of a church but in their homes, bodies, and minds, yet still under clerical direction. Authors strove to validate these new understandings about penance as orthodox and to advertise the benefits of such acts to believers. Although understandably rare, evidence does exist that these messages resonated with English Catholic laypersons suffering from troubled consciences.

Although precedent for such re-interpretations of the forms of penance can be extrapolated from certain late medieval sermon collections, the degree to which English Catholic authors extend the logic and justification for their new practices is novel. It differs from late medieval teachings on penance in England, as well as post-Tridentine and Protestant models of penitential practice and understanding. These authors thus contribute alternative and previously unexplored viewpoints to the vibrant negotiations over penitence, forgiveness, and salvation engaged in by many stakeholders, both Catholic and Protestant, during the Reformation era. As Katharine Jackson Lualdi and Anne Thayer have identified, different understandings of penitence played a large role in the religious lives of lay Christians as well as clerics from the fifteenth to the seventeenth centuries. Its importance extended "beyond a concern for individual sin and salvation to the heart of Catholic and Protestant self-definition and communal identity." This analysis sheds light on English Catholic contributions to these debates and broadens scholars' conceptions of what it meant to be Catholic in Reformation England and Europe.

Additionally, English Catholics' re-negotiations regarding the sacrament of penance are just one example of English Catholic willingness to experiment with a variety of alternatives to traditional late medieval Catholic practices and newer Catholic directives emerging from the Council of Trent (1545-1563). Their de facto attempts to alter subtly many late medieval and post-Tridentine understandings of penance and the role of the priesthood in this sacrament may indicate a greater degree of flexibility within the post-Tridentine Catholic Church than that with which it is usually credited. Although scholars often describe the religious climate of the Reformation era as one of experimentation

\footnotetext{
${ }^{6}$ Katharine Jackson Lualdi and Anne T. Thayer, eds., Penitence in the Age of Reformations, St. Andrews Studies in Reformation History (Aldershot, U.K.: Ashgate, 2000), 1. As Thayer later describes, when Protestant reformers such as Luther questioned penitence, people understood reformers were "going for the jugular of the Catholic Church" (Penitence, 90).
} 
and diversity, they are usually referring to Protestant innovations and variety. Historians typically ascribe the opposite tendency to the Catholic Church, as it began to channel previously diverse religious practices and beliefs into more narrow and well-defined categories. ${ }^{7}$ This English Catholic evidence questions popular perceptions of the Roman Church as unyielding and inflexible, particularly concerning issues of doctrine, the sacraments, and the mediation of the priesthood.

Finally, this examination of English Catholic re-negotiation of the sacrament of penance traces the contours of Catholic life in Protestant England with greater clarity, focusing on evolution of practice and belief rather than the maintenance of institutional forms. It provides new details about the important role played by pastoral clergy serving secretly within England and the choices the laity possessed to work toward salvation. Certainly, priests' critical work on the English Mission and laypersons' efforts to remain loyal to the Roman faith in the midst of persecution have been well documented. ${ }^{8}$ But this study asks scholars to examine adaptations of English Catholic belief and practice in the century after Elizabethan reforms rather than the survival of older practices. Catholics could not simply replicate late-medieval rituals or conform to strictly defined Tridentine instructions on the sacraments. Such directives emphasized that a priest be physically present to mediate for the laity. England had few Catholic priests. But rather than turning to the Church of England for succor, as Protestants hoped and Catholics in Rome feared, some English Catholics experimented with new options.

\section{The Challenges of Performing Catholic Penance in Protestant England}

While the Catholic sacrament of baptism removes the guilt of original sin, humans inevitably sin again later. In order to obtain forgiveness and make satisfaction for these subsequent sins, the Catholic Church orders the sacrament of penance. ${ }^{9}$ In general, this sacrament can be divided into three stages: 1) an examination of one's conscience coupled with true contrition;

\footnotetext{
${ }^{7}$ For example, see Ann Ramsey, Liturgy, Politics, and Salvation: The Catholic League in Paris and the Nature of Catholic Reform 1540-1630 (Rochester, N.Y.: Rochester University Press, 1999).

${ }^{8}$ John Bossy, The English Catholic Community, 1570-1850 (London: Darnton, Longman \& Todd, 1975); Christopher Haigh, English Reformations: Religion, Politics and Society under the Tudors (Oxford: Clarendon Press, 1993); J. C. H. Aveling, The Handle and the Axe: The Catholic Recusants in England from Reformation to Emancipation (London: Blond and Briggs Ltd., 1976).

${ }^{9}$ In the Catholic Church, penance generally refers to three related practices: the sacramental rite of penance, the condition of being repentant, or truly contrite, for one's sins, and the penance
} 
2) confession of sins to a priest who judges and absolves the penitent, returning the penitent to a state of innocence; and 3) the assignment of penance so the sinner can make satisfaction for sins committed. ${ }^{10}$

Church doctrine, based on Lateran IV in 1215 and confirmed at the Council of Trent, specified that a priest must perform the sacrament of penance. ${ }^{11}$ The prereform English church had commanded believers to examine their consciences, confess their sins to a priest, receive absolution from a priest, and perform whatever penance the priest enjoined in order to avoid eternal damnation or the pains of Purgatory and to return to a state of innocence. Although the expectation was that Christians would fulfill this commandment once a year, Eamon Duffy concludes that by the late fifteenth century, many English laypersons began seeking the confessional even more frequently, using the moral precepts taught by confession and penance to guide their spiritual lives. ${ }^{12}$ Anne Thayer suggests this was because priests kept the stakes high by frequently preaching on sin and the imperilment of the soul. Sermons then promoted the sacrament of penance to combat this danger. ${ }^{13}$

undertaken as a corrective (not a punishment) to sin. These second and third understandings of penance can be part of the sacramental rite of penance but could also be assumed independently. The church typically recognizes five types of penance overall: virtue of repentance, sacramental penance, "any prayer, mortification, or other good work imposed either on oneself or by a lawful superior, performed in a spirit of penitence for sin," canonical penance, and public penance. This study is primarily concerned with the first three types. See Donald Attwater, ed., A Catholic Dictionary, 2nd ed., revised (New York: MacMillan, 1949), 376.

${ }^{10}$ For a detailed description of the penitential process, see Thayer, Penitence, 48-67, 93-97. Priests' ability to absolve sin was based upon John 20:21-3: "Receive ye the Holy Ghost: whose sins you shall forgive, they are forgiven them; and whose sins you shall retain, they are retained." The Council of Trent upheld this passage as justifying the priestly power to absolve sins in the sacrament of penance in session 14, can. 3. See Decrees of the Ecumenical Councils, vol. 2, Trent to Vatican II, ed. Norman P. Tanner, original text established by G. Albergio, J. A. Dossetti, P. P. Joannou, C. Leonardi, and P. Prodi, in consultation with H. Jedin (London: Sheed and Ward, Ltd., 1990). Medieval theologians did not necessarily agree on the form which penance should take or how exactly absolution and remittance of the temporal punishment for sin was achieved. For example, Peter Lombard, Duns Scotus, Pedro Martinez de Osma, and the English Lollards all debated the divine institution and necessity of auricular confession. Desiderius Erasmus, in his Annotations, critiqued the traditional scriptural basis used by the Roman church to justify sacramental confession. See Hans Hillerbrand, ed., The Oxford Encyclopedia of the Reformation, 4 vols. (Oxford: Oxford University Press, 1996), 1:402; 3:242-44.

${ }^{11}$ See Henry Charles Lea, A History of Auricular Confession and Indulgences in the Latin Church, 3 vols. (Philadelphia, 1896), 1:230. Trent confirmed penance as a sacrament that was virtuous and a work of satisfaction for the temporal punishment due for sin. Auricular confession before a priest, Trent decreed, was divinely instituted and absolutely necessary to achieve salvation. Trent did not resolve medieval debates regarding the exact manner in which confession delivered forgiveness. See Decrees, vol. 2, especially 6th session and 14th session.

${ }^{12}$ Duffy, Stripping, 60. England's experience appears to run counter to Myers's interpretations of evidence from German areas of the Holy Roman Empire discussed in Poor Sinning Folk.

${ }^{13}$ Thayer, Penitence, 5, 17, 24, 31, 36-37, 43-44, 54, 69-70, 115-17, 120, 185. According to Thayer, preaching served as the "mass media" of the medieval era. Throughout the year, priests 
More frequent confession, however, was impractical and often impossible even before Protestant reforms in England. In order to minimize the penalties for sins committed since one's last confession, priests and books advocated self-examination and contrition coupled with the intent to confess as soon as possible. They, thus, fulfilled most of the first stage of the sacrament of penance: examination of conscience and true contrition. ${ }^{14}$

While pre-reform prayer books encouraged self-examination of conscience, they typically did not suggest self-judgment as post-reform English Catholic authors would later advocate. Instead, the supplicant was instructed to confess to a priest, who would examine, judge, and absolve the sinner, advising proper penance. ${ }^{15}$ The Horae Eboracenses, a pre-reform book of hours following the form of the archbishopric of York, illustrated this delegation of responsibility between the supplicant and the priest. In a question-and-answer format, the Horae Eboracenses addressed basic concerns a layperson might have:

What is confession? Confession is the declaration of sin before a priest or any other in necessity.

What should I do, willing to be confessed? Before all things, in thy bedchamber or other secret place, much and often times think by thyself, where, how, when, with whom, how many times and how enormously thou hast sinned, whether in speaking, consent, will, or deed, what good deed thou left which thou oughtest to have done. . . . And when thou diligently be thyself has discussed and considered all things, then go thou to the priest with great reverence. ${ }^{16}$

Similarly, such pre-reform prayer books did not encourage self-imposition of penance, as English Catholic authors later advised. This too was a priest's responsibility. The layperson's obligation, as the Horae explained, was to feel

encouraged the laity to engage in the penitential process because their eternal souls were at stake, and the laity listened. See also Diarmid MacCulloch, The Reformation: A History (New York: Penguin, 2005), 14-15.

${ }^{14}$ From the late fifteenth century onward, there was a growing body of lay penitential literature to provide spiritual guidance for the confessional and daily life.

${ }^{15}$ See Duffy, Stripping, 58-65, who discusses the manuals used by clerics in the confessional during this period, such as St. John's College, Cambridge, MS S 35, and John Mirk, Instructions for Parish Priests, eds. E. Peacock and F. J. Furnivall (1868; revised, London: Early English Text Society, original series, XXXI, 1902).

${ }^{16}$ Horae Eboracenses: The Book of Hours of the Blessed Virgin Mary with Other Prayers According to the Use of the Church of York from the edition printed in 1536 (Durham: Surtees Society, CXXXII, 1920), 147-48. See also Edgar Hoskins, Horae Beatae Mariae Virginia, or, Sarum and York primers with Kindred Books and Primers of the Reformed Roman Use (London: Longmans, Green, 1901) 133, on the "Form of Confession" typically found in English primers in the 1520 s and $1530 \mathrm{~s}$. 
certain emotions, to resolve not to repeat past mistakes, and to perform whatever penitential acts the priest might assign. ${ }^{17}$ The penitent's primary responsibility remained to follow the instructions of the church as interpreted by a priest who was expected to be physically present before the layperson at some point.

Indications are that sacramental confession before a priest was again the norm during England's brief return to Catholicism under Mary I. Duffy, in his recent examination of Marian Catholicism, argues Mary and Reginald Pole reestablished the Roman faith in England according to the precepts of the Council of Trent, which confirmed the necessity of this traditional sacrament. Duffy's evidence suggests the sacrament of penance may have been instrumental in efforts to reconcile the English with the Roman Church. ${ }^{18}$

Following Elizabeth's Act of Uniformity, however, most Catholics found it difficult to maintain penitential practices in Protestant England. ${ }^{19}$ Some priests working secretly within England attempted to create an environment in which traditional penance was possible. ${ }^{20}$ This proved easiest when a priest resided with a noble or gentry family on a more or less permanent basis. Household members, including servants, could confess to a priest with some regularity. Most Catholics below gentry status who did not live in such households experienced only intermittent contact with priests, but many missionary priests tried to meet their needs. The seminary priest Thomas Clarke, for example, reported that he "heard the confessions of many, mostly poor folks" in his missionary work in Durham. ${ }^{21}$ The story of Catholic priests hiding in the manor houses of wealthy Catholics and risking death to provide the sacraments to neighboring Catholics of lower rank has been told many times. ${ }^{22}$ Such priests considered it one of their primary responsibilities

\footnotetext{
${ }^{17}$ Horae Eboracenses, 34-36.

${ }^{18}$ Duffy, Fires of Faith, 15-17, 133.

${ }^{19}$ The Church of England continued the act of confession but in a non-sacramental form as will be discussed below. An English Catholic with a troubled conscience could not simply go into a Protestant Church, confess to a Protestant priest, and get the same result as with the Catholic rite performed by an ordained Roman Catholic cleric. To the Catholic mind, there was no salvific grace accrued with the Protestant ritual.

${ }^{20}$ As part of what was known as the English Mission, Englishmen studied at seminaries on the Continent and returned to England as missionaries to replace the dwindling numbers of Marian priests. The mission began after William Allen, a Lancashire priest and emigrant, founded an English College attached to the University of Douai in the Spanish Netherlands in 1568.

${ }^{21}$ Public Record Office, Kew, State Papers Domestic Series (hereinafter as SP Dom), 12/244/5.

${ }^{22}$ For examples of such analyses, see Michael C. Questier, Catholicism and Community in Early Modern England: Politics, Aristocratic Patronage and Religion, c. 1550-1640 (Cambridge: Cambridge University Press, 2006); E. E. Reynolds, Campion and Parsons, The Jesuit Mission of 1580-1 (London: Sheed and Ward, 1980); Bossy. The English Catholic Community; Haigh, "The Continuity of Catholicism in the English Reformation," Past and Present (GB) 93 (1981): 37-69; McClain, Lest We Be Damned, 20, 37-39, 93, 221; K. R. Wark, Elizabethan Recusancy in Cheshire (Manchester: Chetham Society, third series, XIX, 1971); S. J. Watts, From Border to Middle Shire: Northumberland 1586-1625 (Bristol: Leicester University Press, 1975); J. C. H.
} 
to offer Catholics the opportunity to confess and receive the sacrament of penance as frequently as possible. ${ }^{23}$ The Benedictine Ambrose Barlowe exemplifies such efforts as he attempted to gather Catholics from a variety of backgrounds together for prayer and penance during the early decades of the seventeenth century. One observer chronicled Barlowe's followers' preparations for Christmas, describing winter in the northern shires where Barlowe ministered. Diverse Catholics, old and young, braved harsh weather to arrive at the priest's door. The observer called the visitors "penitents" and commented upon their fervor. Barlowe had erected an altar on which he placed a picture of Jesus and burned wax candles (that he had helped make). The penitents gathered around the altar to pray. The observer remembered:

I have still had a great desire to express how much I was edified in that place by the Pastor and his penitents, who seemed to me to represent the good Catholics in the primitive church. They so truly united in Charity (coming from several places), rejoiced to meet one another in that holy exercise, they spent the night modestly and devoutly, sometimes in prayer before the altar, otherwhiles singing devout songs by the fireside. ${ }^{24}$

Even if this author perhaps exaggerated the piety of those gathered, he or she opened a window upon one type of opportunity open to a limited number of English Catholics to be penitent. While the observer did not mention whether the actual sacrament of penance was performed complete with confession and absolution, the observer did make clear that a priest was present to direct the penitential acts that were performed. The priest acted as spiritual guide, leading and structuring a large part of the experience of penance. Moreover, it seems likely that the sacrament of penance was performed considering the importance English priests placed on providing opportunities for this sacrament whenever possible.

Many laypersons wanted to confess. Priests incarcerated in prisons or who visited prisons frequently offered the sacrament of penance to any Catholics present. In the Fleet prison in London in March 1594, for example, the Protestant spy Benjamin Beard reported that a number of Catholic prisoners and visitors had confessed to priests who were present at the Fleet. Although the sacrament of penance had been performed, Beard claimed that the Catholics

Aveling, Northern Catholics, The Catholic Recusants of the North Riding of Yorkshire, 1558-1790 (London: Dublin Chapman, 1966).

${ }^{23}$ For further examples of mission priests hearing confessions, see SP Dom 12/248/43 and Richard Challoner, Memoirs of Missionary Priests and Other Catholics of Both Sexes that have Suffered Death in England on Religious Accounts from the Year 1577-1684, vol. 1 (London: Burns, Oates \& Washbourne, Ltd., 1924), 29, 42, 68, 73, 154, 194, 383, 396, 410, 440, 464, 476.

${ }^{24}$ W. E. Rhodes, ed., The Apostolical Life of Ambrose Barlow, Chetham Miscellanies, new series, ii (Chetham Society, new series, LXIII, 1909) 10. 
had been too scared to have a Mass after they learned that the Protestant authorities had arrived at the jail. ${ }^{25}$ Similarly, in his autobiography, the Jesuit missionary John Gerard reported that many laypersons approached him, asking him for help in examining their consciences and setting times to confess and receive the sacrament of penance. $^{26}$

But such attempts, however courageous, were impractical in the long term since most Catholics would not have regular access to priests. Medieval preaching in England had stirred up fears about sin and damnation and the necessity of sacramental confession. Church doctrine, as mentioned above, specified that a priest must perform this sacrament. If a priest were unavailable to perform the sacrament or to lead penitential activities such as Barlowe's, what could English Catholics do?

Some clerics working in England saw lay Catholics struggling with this dilemma and endeavored to help. They wrote and distributed books to laypersons instructing them how to examine their consciences in preparation for confession and the sacrament of penance. ${ }^{27}$ But, recognizing that the demand far outpaced the ability of priests to provide the sacrament, were these pastoral authors advocating confession and promoting penance along the same lines as they had in pre-reform England or post-Tridentine Europe? Upon examination of many such treatises, the answer is "no." These authors negotiated between Roman orthodoxy and the needs of English Catholics attempting to maintain their faith in a Protestant country. As such, we must read these texts differently from the apologetical or doctrinal works penned by English Catholics in exile in continental Europe. Writing for a readership familiar with such restrictions, the clerical authors examined here developed new understandings about sacramental penance that met the needs of the Catholic Church and its believers. In so doing, they added an alternative Catholic viewpoint beyond that articulated by Trent to the heated debates surrounding penitence, forgiveness, and salvation engaged in by all Christian faiths during the Reformation era.

\section{Meeting the Challenge: New Understandings And Performances of PenAnce}

The English seminary priest John Radford, in his 1605 treatise, A Directorie Teaching the Way to the Truth in a Briefe and Plaine Discovrse against the

\footnotetext{
${ }^{25}$ CSP Dom 12/248/43. See also William Weston, William Weston, The Autobiography of an Elizabethan, trans. Philip Caraman (London: Longmans, Green and Co., 1955), 154, 167, 201; Pollen, Unpublished Documents, 1:265, 287; CSP Dom 12/97/27.

${ }^{26}$ John Gerard, The Autobiography of a Hunted Priest, trans. Philip Caraman (Garden City, N.Y.: Image Books, 1955), 46-47, 50, 60, 64.

${ }^{27}$ For examples, see CSP Dom 12/244/5, 12/248/43, 12/248/116.
} 
heresies of this time, argued that God was not so bound by his sacraments that he could not deliver his grace without them. Radford admitted that it was preferable to make a full confession and receive absolution and penance at the hands of a priest. If this proved impossible, however:

Christ hath commanded that we confess our sins ... as soon as he can meet with a lawful Priest, or in due time he will confess then; that so Christ's ordinance being fulfilled by means of the Priest, they may be forgiven him. But if man be in danger of death or in such place that he cannot come possibly by any mean to confession before a Priest; then no doubt, if he have perfect contrition and sorrow for his sins, Christ, the high Priest $\ldots$ giveth in such times of necessity perfect absolution from $\sin ^{28}$

Authors such as Radford and the former Jesuit Thomas Wright attempted to show English Catholics how to use what religious tools they still possessed to achieve this "perfect contrition and sorrow" to answer to God directly for their sins so that they would be granted "perfect absolution from sin." As Wright proposed in his The Passions of the Mind in General, God gave man many "internal gifts" - such as faith, hope, charity, and the grace of the Holy Spirit - with which man may combat sin and redeem himself. Similarly, God provided excellent examples - such as the scriptures and the lives of the saints - to show man how to "die to old Adam and live with Christ, crucify sin and follow virtue." Wright maintained that, "to be brief, no man can say that God hath been a niggard with him; but that he hath been unanswerable to God." 29

Some pastoral authors searched for a variety of options they might present to English Catholics to encourage confession and penance within the restrictive environment of England. The traditional instruction to possess the "intent to confess as soon as was practical" took on new meaning for English Catholics who had little access to priests, and these authors understood this. For clerical authors of such treatises, it was largely a matter of stressing the function of the sacrament rather than its institutionalized form. As discussed above, the institutionalized form of the sacrament of penance consists of three stages: examination of conscience/show of contrition; confession to a priest, followed by judgment and absolution by a priest; and satisfaction, or the assigning of penance by a priest, which the penitent then performs. In

\footnotetext{
${ }^{28}$ John Radford, A Directorie Teaching the Way to the Truth in a Briefe and Plaine Discovrse against the heresies of this time (n.p., 1605), 104-5. See also Henry Garnet, The Societie of the Rosary (n.p.d.: 1596/7), 34-35; William Stanney, A treatise of penance, with an explication of the rule, and maner of living, of the brethren and sisters, of the Third Order of St. Frauncis, comonli called of the Order of Penance, ordained for those which desire to leade a holy life, and to doe penance in their owne houses, Part I (Douai: John Heigham, 1617), 65.

${ }^{29}$ Thomas Wright, The Passions of the Mind in General, ed. William Webster Newbold (New York: Garland, 1986), 319-20, 323.
} 
essence, English authors reinterpreted the second and third stages - the priest's traditional role in the sacrament through auricular confession, judgment, absolution, and assignment of penitential exercises. Such authors advocated self-examination of conscience, confession directly to God, self-judgment, absolution directly from God, and self-imposition of penance when a priest was not available.

One of the greatest challenges faced by these authors was to reframe these innovative understandings about penance in a manner that would be considered orthodox by Rome. Such authors did not intend to challenge church doctrine on the role of priests as mediators, nor did they intend to discourage confession and penance before a priest if one could be found. But, understanding that priests usually would not be on hand, these authors downplayed the strict injunction to confess before and be judged and absolved by a cleric.

In step-by-step fashion, the anonymously authored "A Praier of Confession and Repentence," included in the seventeenth-century Selected Praiers and devotions for severall occasions; and for all the yeare, found in the Harleian MSS of the British Library describes the process of self-examination of conscience, confession directly to God, self-judgment, absolution directly from God, and self-imposition of penance. ${ }^{30}$ The writer of Selected Praiers intended this work to be used by families gathering at home for communal worship. ${ }^{31}$ The prayer called such action "confession" and some of the phrases of the prayers were similar to those used by a priest in the sacramental rite of penance. One wonders how much difference an ordinary layperson with a troubled conscience would have or could have made between these prayers and the ones said by a priest.

In the manuscript, at the beginning of the confession, the supplicant at first expressed unworthiness to approach God directly and prayed:

Thou also, o Lord, beholdest, how I, a wicked and sinful wretch, have with my manifold sins and iniquities grieved and offended thee. I have sinned against Heaven and earth, and am unworthy to come before thee.

Yet English Catholics had to trust in a direct relationship with God. This author, agreeing with the anonymous author of the prayer that opened this article, bemoaned that English Catholics had few others to intercede for them.

I have sinned yet I am thine, and in Thee is all my trust. If thou cast me forth, who will receive me? If thou despise me, who will look upon me? To whom, oh Lord, shall I go, or whither shall I fly; but only unto Thee, in whom is all my Hope?

\footnotetext{
${ }^{30} \mathrm{BL}$, Harleian MS 4149, ff. 14-17. Each page was marked with the sign of the cross.

${ }^{31}$ Harleian MS 4149, ff. 10-10v.
} 
Directly addressing God, the believer began to confess without the aid of a priest:

Be merciful therefore to me, and in thy favor look upon me. O hear my prayer and hearken to my confession: for unto thee do I confess my sin and acknowledge mine iniquity.

At first the confession was a general admission of fault:

O God, my heart hath conceived sin and brought forth vain imaginations: my will and my desires have been wicked, and my works abominable. My eyes have taken delight to see vanity, and my ears to hear it; my tongue to speak it, my Hands to do it, and my feet to walk in it.

But then the supplicant was to divulge specifics:

Many have been the sins of my youth; and many are the sins of mine age. Sins of omission, and sins of Commission: (Here confess such sins in particular, as Thou art guilty of, and canst call to mind).

The author constructed a "fill-in-the-blank" section so that the believer could insert individual sins into the confession. A priest would have required the specifics of a penitent's sins, and the author of this prayer expected his readers to conform to this expectation even when a priest would not be present to hear the confession. Many of these English Catholic pastoral treatises contain long lists of questions the penitent should ask himself or herself about what sins they might have committed, reminiscent of the late medieval manuals of confession produced for use by priests when questioning their parishioners. The difference is that now the list of questions was being provided directly to the laypeople without the faceto-face mediation of the priest.

After this self-examination, which the author terms "confession," the show of contrition and request - made directly to God — for absolution began. The prayer used phrases that Catholics might have recognized as traditional Catholic prayers, yet the author emphasized again that the supplicant made this confession directly to God, not to a priest. The supplicant was to enumerate his many sins and then profess:

the Burden of them is intolerable. I am right sorry for them o Lord; and the sight of them is grievous unto me. I confess them, o Lord, unto Thee; and from the bottom of my heart repent me of them. Oh be merciful, be merciful to me and hear my humble confession and accept my repentance. Oh let mine eyes gush forth into tears, and my very soul be contrite and broken with the sense of these grievous Transgressions, that my confession may be entire, and unfeigned and my repentance true. 
The supplicant went, step by step, through the requirements of the first stage and part of the second stage of penance: examination of conscience, contrition, and confession are all here.

Then the believer petitioned directly to God for absolution. The prayer clearly implied that this type of confession would be helpful in remitting sin and saving the soul. The believer prayed:

that Thou ... mayest be merciful unto me to blot out my sins and to wash away all mine iniquities. Oh, purge me and I shall be clean. Wash me, and I shall be whiter than snow.

This author employed Mary Magdalene, that saint who was said to have confessed directly to Christ and earned salvation from him, to show the efficacy of this type confession.

Remember me, Lord, and be merciful to me, who receivedst into thy favor Mary Magdalene . . . . Say unto my soul that Thou art my Salvation . . . . Oh Thou who art Savior of the World, save my Soul. . . . And O Good God, Let this my Confession and Repentance be acceptable before Thee, even to the remission and forgiveness of all my sins. And whatsoever through my frailty happens to be wanting, either to the Integrity of my Confession or to the Sincerity of my Contrition and repentance, let the Goodness and the merits of thy dear son, my savior, make up and perfect, and thy mercy, pity and compassion graciously supply. ${ }^{32}$

English Catholics might hope that they could repeat the Magdalene's success. And if anything were missing from this type of confession and penance, supply it, Lord, please, the believer pleaded. The author ended with the Lord's Prayer, one of the prayers traditionally assigned by priests to their parishioners as part of the process of penance.

The author presented this type of self-examination, confession to and absolution directly from God, and satisfaction as conferring similar if not identical benefits as traditional sacramental penance. Souls would be "washed," "clean," "whiter than snow." Let this confession be enough, believers prayed, "even to the remission and forgiveness of all my sins." Some English Catholics wanted to believe this. They needed to believe this. No matter the author's theological or doctrinal position, some lay readers would probably not have the theological sophistication to make distinctions between the sacrament and this type of prayer.

\footnotetext{
${ }^{32}$ Emphasis original. For discussion of different interpretations of Mary Magdalene as an aid to sinners, see McClain, "They Have Taken Away My Lord: Mary Magdalene, Christ's Missing Body, and the Mass in Reformation England," The Sixteenth Century Journal 38, no. 1 (Spring 2007): $77-$ 96; Thayer, Penitence, chapter 4.
} 
Other authors attempted to show English Catholics how to use what religious tools they still possessed to answer to God directly for their sins and be forgiven. ${ }^{33}$ In his translation of $A$ treatise of penance published in 1617, the Franciscan William Stanney counseled readers how to examine one's own conscience, confess to God, pass judgment upon oneself, and engage in penitential exercises to achieve satisfaction, similar to the prayers in the Harleian MS. Although Stanney encouraged membership in the penitential Third Order of St. Francis, he recognized in his translator's preface that the original treatise had been written in a "Catholic country [France] (where all virtuous actions, and pious devotions are freely practiced)" and that it would be impossible for Englishmen to engage in the same activities. He freely admitted that he altered some of the original author's prescriptions and claimed his goal was to eliminate all doubts and difficulties English readers might experience in adopting the practices of the order and to "accommodate it ... unto the convenience of the persons, time, and place of our Country."34

Stanney suggested that the believer should "make an account between God and his conscience." ${ }^{35}$ According to Stanney, as an English Catholic sat alone after having gone through the self-examination of conscience, the contrition, and the confession, the believer should then listen to what his conscience counseled, judge himself, and make satisfaction. As with the Harleian MS, there was no mention of the priest who traditionally would have judged the sinner. The conscience guided by God was a penitent's "chief accuser. If thou wilt obey and give ear unto it, thou shalt hear what thou must do."36 Penitents must then "judge themselves and being sorry for their sins, do some penance for them, knowing that God our most loving Father . . . doth not punish twice the same thing," thereby fulfilling the functions of penance. ${ }^{37}$

In the third book of his The Passions of the Mind in General, Thomas Wright offered each reader the means to "know his own inclination and to what Passions his Soul most bendeth" so that he may henceforth "moderate and mortify" those passions. ${ }^{38}$ Likely written during his early years of

\footnotetext{
${ }^{33}$ Stanney, A treatise of penance, 354-59; Wright, Passions, 150-201, 319-20, 323. For further examples of examinations of conscience, see Garnet, The Societie, 196-97; Arthur Crowther and Thomas Vincent, The Dayly Exercise of the Devout Rosarists Containing several most pithy Practices of Devotion: profitable not only for such as are members of the sacred Rosary, but also for all pious Christians (Amsterdam: 1657), 35-39.

${ }^{34}$ Stanney, A treatise, Epistle of the translator.

${ }^{35} \mathrm{~A}$ lay order established in 1221 that sought a return to the austere practices originally established by St. Francis of Assisi. Stanney, A treatise, 354-59.

${ }^{36}$ Stanney, A treatise, $358-59$.

${ }^{37}$ Stanney, A treatise, 110-11.

${ }^{38}$ Wright, Passions, 147, and also 102, 152-53. This former Jesuit wrote and published Passions in England with license of the government, ostensibly as a secular book. One of the functions of this work, however, was clearly to provide instruction of a religious nature with strong Catholic inclinations. Ginevra Crosignani, "De Adeundis Eclesiis Protestantium": Thomas Wright, Robert
} 
incarceration between 1596 and 1597, Wright's popular treatise was first published in 1601 with a second edition in 1604. Wright entered England following his dismissal from the Society of Jesus in 1595 due to his oftstated support of Elizabeth I and his willingness to condemn Spain for any attempts to unseat the queen. No longer a Jesuit but still a Catholic priest, Wright sailed openly into England to begin his controversial experiment in toleration, which involved surrendering himself immediately to Protestant authorities, informing Elizabeth's government about Spanish plans to invade England, and publicly advocating unwavering support of the queen's political authority. He wanted to prove English Catholics were good, loyal subjects, but he saw no contradiction in them being good, loyal Catholics as well. Wright continued to act as a priest, converting some of Elizabeth's subjects to Catholicism. After a brief period of freedom, Wright was imprisoned. ${ }^{39}$ In what was perhaps a thinly veiled criticism of the Calvinist practice of public confession, Wright counseled readers not to confess their passions publicly. Your enemies, Wright argued, might use your weakness to your disadvantage, tempting you into $\sin .^{40}$

After ferreting out one's inclination to sin, Wright advised critical selfjudgment. Wright, acting as many a priest would, comforted mild sinners. The more inclined one was to sin, however, the stronger and more forceful the remedy. The remedies Wright advocated ranged from diverting one's thoughts and avoiding occasions when one's passions might be enflamed to "scarceness in diet" and avoidance of pleasure. In cases in which a reader could not control his passions, Wright proposed that he "bridle the body, that is, to chastise it." Wright suggested traditional penitential acts such as fasting, praying, sleeping upon the hard ground, wearing of hair shirts, and subjecting oneself to "pinching cold" to promote virtue and quell passions. ${ }^{41}$

If readers would follow these priests'/authors' instructions, they were told that they would avoid dying in mortal sin. Stanney recognized that his readers feared for their souls in the absence of priests to perform the sacrament of penance. The key was that:

everyone having done Penance, according to the quality of his offence, either in act or in will, he might rest and sleep in security, which otherwise with

Parsons, S.J., e il dibattito sul conformismo occasionale nel'Inghilterra dell'età moderna, Bibliotheca Instituti Historici 56 (Rome: Institutum Historicum S. I., 2004) discusses other examples of Wright's support for dissimulation and limited conformity. For a discussion of dissimulation, see McClain, Lest We Be Damned, 53-54.

${ }^{39}$ His affiliation with the Essex faction likely played a roll. See Theodore A. Stroud, "Ben Jonson and Father Thomas Wright," English Literary History, 14, no. 4 (December 1947): 274-82.

${ }^{40}$ Wright, Passions, $155-58$.

${ }^{41}$ Wright, Passions, $150-53$. 
assured repose of Conscience he could not do, not knowing in what dangerous estate he standeth, being assured that God will not forgive sinners, and the pains due thereunto, unless the sinner shall first do penance for them, by hearty contrition and full purpose of confession when he may conveniently, with satisfaction in like sort . . . for either the sinner must punish his own offense in himself by doing Penance, or else God in his wrath will chastise it . . . that whoever doth with sorrow for his sins, but meanly punish himself God will not inflict any other punishment for his former offenses, as the Apostle S. Paul doth insinuate, saying, "If we judge ourselves, we should not be judged." In which words the Apostle doth manifestly show that the cause wherefore we are judged and punished by God is, for that we neither judge or punish ourselves. ${ }^{42}$

Stanney made it clear when he was discussing the benefits of penance that he was referring to self-imposed penance. He argued from Ezekiel that God would remember the atonement for sin rather than the sin itself and continued that this was so:

especially if he [the penitent] exercise true justice upon himself, which requireth that according to the greatness of the sin, so should the penance be correspondent thereunto. Therefore must he first judge of the offense, and then use condign justice upon the offender, that is, himself, poor sinner, whose Penance ought not to be small .... [Penance] saveth from eternal death, blotteth out not only the sins, but the very memory thereof also, giveth life to the soul, and preserveth it from ruin and eternal pains, which we take in doing thereof, doth deliver and preserve us from the endless pains of hell.

Stanney's self-imposed penance, in other words, appears to accrue the same benefits as the actual sacrament: "life to the soul," a return to a state of grace, the salvation of the soul. Stanney never directly advised his readers that these practices were a substitute for the actual sacrament of penance or that the benefits accrued were identical. Stanney's phrasing made it possible for laypersons reading his advice to believe that God would forgive their sins if each supplicant was contrite, confessed before God, sentenced himself to penance, and possessed the intent to confess to a priest when it became possible. Stanney ambiguously left it to the reader to interpret optimistically phrases suggesting that this type of penance "doth deliver and preserve us from the endless pains of hell" and that "(God) will accept of our penance and by his loving verity, he will perform what he hath promised for it: that is, his grace." $" 43$

\footnotetext{
${ }^{42}$ Stanney, A treatise, $109-10$.

${ }^{43}$ Stanney, A treatise, 55-57, 63.
} 
In other words, these priests appear to advise their readers than an examination of conscience and confession performed alone before God followed by penitential acts of satisfaction were strong tools English Catholics possessed to obtain forgiveness of sins and attain salvation. English Catholics could gain absolution - the missing part of step two of the sacrament of penance - and avoid the pains of hell or Purgatory for offenses committed on earth if they judged and punished themselves according to Stanney's instructions. The members of Stanney's order, for example, by their small inconveniences and pains of practicing penance:

in examining, being contrite and punishing their own faults, do surely obtain so great a benefit as to be freed from future pains, and be absolved, both at their entrance and hour of death also, from all their sins and pains due thereunto in Purgatory, and be restored again at their last hour, to that estate as it were of innocency, wherein they were when they were first baptized and after this transitory life, to pass securely by God's grace to eternal glory. ${ }^{44}$

One thing that stands out in these pastoral works is the regular absence of the term "priest" or "cleric" in the wording of the texts. While it might appear that authors such as Stanney and the author of "A Praier of Confession and Repentence," bypassed the priestly role in a manner reminiscent of reformers' discussion of a "priesthood of all believers," these authors did not advise readers that they became priests themselves. A priest's mediation just took on a new form. In many ways, the clerical authors stood in for the usual parish priest to whom a Catholic would confess. They tried, through print, to ensure that readers would perform a similar sort of ritual as they would have had a parish priest been available. ${ }^{45}$ Such authors could not, of course, provide absolution for confessions they had never heard. They could, however, still serve as spiritual counselors to Catholics by providing as detailed instructions as possible (and some of these instructions are intensely detailed) to teach their lay and clerical readers how to make a confession, earn forgiveness of sin, and effect a reconciliation with and absolution from God without a priest's physical presence since being in the physical presence of a priest was simply not possible for most English Catholics.

Interestingly, the majority of authors who made such recommendations to their lay readers were not Jesuits. Neither Robert Southwell and Robert Persons, for example, two of the most eloquent English Catholic writers, provided detailed instructions for self-examination of conscience- let alone self judgment and self-imposition of penance - in their best known guides

\footnotetext{
${ }^{44}$ Stanney, A treatise, 113-14.

${ }^{45}$ For example, see Dedicatory in Stanney, $A$ treatise, A2v-A3.
} 
for English Catholics: Southwell's A Short Rule of Good Life and Persons's A Christian Directorie. Perhaps this is understandable given that Ignatius Loyola had already provided directions for self-examination of conscience contained in the First Week of the Spiritual Exercises. ${ }^{46}$ Both authors wrote their guides for all Christians wishing to live lives of Christian virtue. Neither refers specifically to, or makes accommodations for, English Catholics' restrictive circumstances. Southwell, for example, advocated confession twice weekly to his readers, or at least every six months, which accords with Jesuit rules. Both Southwell and Persons promoted the sacrament of penance in these works but stressed the Roman Church's mediating role. Persons, in particular, repeatedly emphasized the authority of, and obedience due to, the priesthood and the Christ-given role of the Church in absolving sins. ${ }^{47}$ In light of the larger Jesuit priorities of strengthening pastoral relationships between priests and laity and upholding papal authority in light of Protestant gains in the Reformation era, perhaps this is not surprising. This phenomenon merits further inquiry but is outside the scope of this present analysis.

The authors discussed here who did not place strong emphasis on the Church's mediating role in penance did not intend to challenge Catholic doctrine on the role of priests as mediators or to discourage sacramental penance before a priest if one were available. One of the authors' primary concerns was that their suggestions to believers fall within the bounds of orthodoxy. To have strayed outside these bounds would have endangered the souls of the very people for whom they were trying to care. In fact, by creatively adapting the church's traditional instructions for confession and penance, these priests were helping preserve the church's chain of command and the pastoral role of priests in function if not in traditional, institutional form.

Such clerical authors justified their adaptations on the basis of the Roman Church's traditional "exception to the rule" - cases of extreme necessity. Roman doctrine had always allowed that God could confer grace in the absence of priests and the sacraments in times of emergency. ${ }^{48}$ For example, midwives might baptize dying babies if a priest were not available. A man dying alone might make a last confession of his sins and cleanse his soul without a priest's final absolution. The traditional instructions for emergency situations regarding the sacrament of penance, reiterated by authors such as Radford and Stanney, to possess the "intent to confess as soon as was

\footnotetext{
${ }^{46}$ Ignatius Loyola, Spiritual Exercises, First Week, exercises 21-44.

${ }^{47}$ Robert Southwell, A Shorte Rule of Good Life, York Minster Library, Add MS 151, chapter 5, 11. 69-72; chapter 6, 11. 138-46; chapter 7, 1. 21; chapter 9, 1. 49; chapter 10, 11. 62, 128-30; chapter 11, 11. 57-58, 354; Robert Persons, A Christian Directory, Guiding Men to Their Eternal Salvation (orig. 1582; repr. Liverpool: John Sadler, 1754), 215-16, 233-41, 283, 294, 299-365, 621-22.

${ }^{48}$ New Catholic Encyclopedia (New York: McGraw Hill, 1967) xii, 996.
} 
practical" took on new meaning, however, for English Catholics who enjoyed long-term limited access to priests. The distinction between Roman doctrine and the English examples is that what the Roman Church had hitherto taught as the exception only to be used in isolated cases of extreme necessity had now become the day-to-day rule in England. The continual situation in England was one of extreme necessity.

\section{Persuading English Catholics to Accept Reinterpretations of Penance}

An investigation into the recommendations in these pastoral texts is valuable in and of itself for the light it sheds on English Catholic lay and clerical cultures. ${ }^{49}$ It suggests methods clerical authors used to succor a flock of English Catholics to which they could not minister personally and the menu of options available to lay Catholics concerned for the fate of their souls. Moreover, in comparison with my previous work on English Catholic reinterpretations of the sacrament of the altar, this study of penance suggests continuity in approaches taken by some English clerics to de-emphasize or reinterpret traditional rituals and sacraments so their countrymen might work toward salvation. ${ }^{50}$

Ascetic penitents were often held up before English Catholics to advertise the fruits of self-judgment and self-imposition of penance. Robert Simpson, for example, a missionary priest who apostatized, was believed to have earned God's forgiveness through his penance. Protestant authorities arrested Simpson in Derbyshire in 1588 and condemned him to death. Simpson feared execution and began to conform, eventually repudiating Catholicism. Reprieved from his death sentence but still incarcerated, Simpson met two Catholic priests, Garlick and Ludlam, who convinced him to return to Catholicism. Turning his back on Protestantism, he imposed severe penance upon himself to repent of his sin. In July 1588, Simpson was executed along with Garlick and Ludlam.

Verses memorializing Simpson revealed the public perception that Simpson's self-imposed penance adequately redeemed his soul.

And what if Simpson seemed to yield

For doubt and dread to die;

He rose again, and won the field,

And died most constantly

${ }^{49}$ As Thayer has commented, "to understand the lay religious situation of late medieval Europe, we do well to look at teaching designed for and delivered to the laity" (Penitence, 4).

${ }^{50} \mathrm{McClain}$, Lest We Be Damned, chapters 3 and 4. 
His watching, fasting, shirt of hair

His speech, his death and all,

Do record give, do witness bear

It wailed his former fall. ${ }^{51}$

Simpson, in Christ-like fashion, "rose again." He had committed one of the greatest sins by publicly renouncing his religion, and yet English Catholics were told that Simpson won the day through devout prayer, abstinence, and austerity.

Simpson's example, though powerful, was atypical of day-to-day English Catholic experience and too austere to encourage many English Catholics to assume a similar yoke. How might writers have convinced average English Catholics to adopt the more moderate penance that they advertised in these printed texts? How could they persuade English Catholics to examine themselves, confess directly to God, judge themselves, and perform penitential acts?

First, they had to legitimize their adaptations of the traditional penitential message to which English Catholics were accustomed. Second, they had to tout the benefits of self-examination, self-judgment, and self-imposition of penance. To legitimate their efforts, English authors constructed a pedigree for their new prescriptions based on English history, scripture, and the writings of the most respected church fathers. Writers most often appealed to the New Testament, particularly the writings of Paul and the story of the penitent Mary Magdalene. Also prominent, however, were invocations of Old Testament figures, such as King David and the prophets Ezekiel and Jeremiah. $^{52}$ By drawing upon such respected sources, authors focused heavily on the spiritual comfort and saving grace that a person fearing for the health of her soul might attain through the re-conceptualized penitential practices advertised in these works.

Some authors validated their recommendations by appealing to specific penitential traditions of England. Stanney, for example, asked readers to imitate two of England's most recent Catholic queens: Katherine of Aragon and her daughter, Mary I. Stanney encouraged readers to adopt a penitential lifestyle by describing Katherine's reverence for penance. In addition to confessing twice or three times weekly and communicating once weekly, Katherine spent six hours in prayer at church daily, Stanney told readers. She reportedly prayed on her knees on the cold pavement. She ate moderately and "wore proper tertiary clothing under her gowns."

\footnotetext{
${ }^{51}$ Printed in Challoner, Memoirs (1924 ed.), 133, quoted in Patrick McGrath, "Apostate Priests and Naughty Priests in England under Elizabeth I," in Opening the Scrolls, Essays in Honor of Godfrey Anstruther, ed. Dominic Aidan Bellenger (Bath: Downside Abbey Trustees, 1987), 69.

${ }^{52}$ Stanney, A treatise, $50-53$.

${ }^{53}$ Stanney, A treatise, 239-40, 283, 299.
} 
half sister and immediate predecessor, also joined Stanney's order, the penitential Third Order of St. Francis. ${ }^{54}$

More commonly, however, authors of these English Catholic texts constructed a pedigree for self-examination, self-judgment, and self-imposition of penance based upon scripture and the writings of eminent theologians of the early Christian Church. For example, the Benedictines Arthur Crowther and Thomas Vincent, in their 1657 work The Dayly Exercise of the Devout Rosarists Containing several most pithy Practices of Devotion: profitable not only for such as are members of the sacred Rosary, but also for all pious Christians, attempted to legitimize these practices by citing the advice of the apostle Paul. "Let everyone examine and prove his own Works (Galatians 6)," Paul exhorted. Crowther and Vincent also consulted the prophet Jeremiah who encouraged "Let us all search narrowly, sift thoroughly, peruse diligently our own ways and works; Let's all summon ourselves to render a strict account of our life, actions, and conversation." 55 According to scripture, these authors maintained, God would not punish a sin for which man had already atoned, that "penance blotteth out the very memory of $\sin . " 56$ It was the act performed (penance) that garnered forgiveness rather than the individual (the priest or the layperson) performing the act. $^{57}$

After having constructed this type of powerful pedigree and justification for self-examination of conscience, self-judgment, and self-imposition of penance that they hoped would resonate with English Catholics, the next task these authors faced was to convince readers of the benefits of adopting their recommendations. The profits, they claimed, were God's saving grace and a closer relationship with Christ. These writers felt that there were some popular prejudices against such self-judgment and self-imposition of penance that would have to be overcome. Why, English Catholics might wonder, should they voluntarily assign themselves inconvenience, discomfort, or even pain? The English priest John Bucke, in his 1589 Instructions for the use of the beades, hoped a story might change perceptions.

\footnotetext{
${ }^{54}$ Stanney, A treatise, Epistle of the translator.

${ }^{55}$ Crowther and Vincent, Dayly Exercise, 35-39. See also "Castigo corpus meum et in servitutem redigo," 1 Corinthians 9:27, and "Mortificate membra vestra quae sunt super terram," Colossians 3:5, quoted in Wright, Passions, 91-92; Stanney, A treatise, 55-57, 184, for justifications from St. Basil, Dionysius the Carthusian, and the abbot Pynusius.

${ }^{56}$ Stanney, A treatise, $55-57$. Stanney made clear, as mentioned above, that he was referring to self-imposed penance.

${ }^{57} \mathrm{~A}$ convenient application of ex opere operato to meet the needs of English Catholics. Thomas Tentler and, more recently, Anne Thayer delve deeply into doctrinal debates surrounding confession and penance in the medieval and Reformation periods. Interestingly, these English Catholic authors do not make significant mention of the theological debates over sacramental penance engaged in by prominent medieval theologians such as Peter Lombard, Thomas Aquinas, and Duns Scotus discussed by Tentler and Thayer. Tentler, Sin and Confession; Thayer, Penitence, esp. chapter 4.
} 
Bucke's story addressed one of the most common misconceptions about penance: that penance was meant to cause pain or discomfort as punishment for only the most corrupt sinners. In secular justice, after all, the worse the offense, the worse the punishment. One's family or neighbors likely would perceive any voluntary adoption of restrictive penitential measures as a tacit admission that an individual had committed heinous sins.

To counter this perception, Bucke told the tale of a thief who adopted a penitential lifestyle after observing the habits of a devout monk. According to Bucke, the monk's abbot hoped to convince the thief to do good and ordered the monk to serve the thief. The monk was to give the thief whatever he demanded, and the thief and monk were always to eat and drink together. The abbot, however, commanded the monk to subsist only upon bread and water, no matter what the thief consumed.

The monk well performed what was commanded. In continuance of time, the thief observed the diet of the monk, and being somewhat amazed therewith all, he asked the monk what great offence he had committed, any murder, incest, or great crime. No, said the monk, I am not culpable of any heinous act. But this austerity I use to the end that the king of all kings may be more merciful to me at the latter day where every man's deeds shall appear.

The monk fasted in atonement for transgressions he might have committed. He comforted himself in this life with a comparably light penance, thereby decreasing his fears over what might happen at his Judgment. According to Bucke, the monk so impressed the thief that the thief joined the order and adopted a similar penitent lifestyle. ${ }^{58}$

Bucke attempted to communicate that penance was a positive act, not a negative one. It signified the releasing of a burden rather than the taking up of one. A clear conscience could bring not only relief, but "jubilees of the heart." Wright likened the experience to a "great cluster of grapes," plump and succulent, hanging heavy on the vine, that go unpicked because Christians "fly mortification" and "attain not unto the sweet spiritual consolation of Christian charity.",59

Stanney asked, "What is the cause therefore that this way seemeth unto many to be so hard and painful that so few will pass thereby?" He concluded that people rejected penance because they had never tried it. The journey always seems rough and hazardous to those who have never set their feet upon the road. For example, sailors who sailed to the Indies, Stanney argued, would be more credible judges as to what direction to go and what gains could be

\footnotetext{
${ }^{58}$ John Bucke, Instructions for the use of the beades (1589; repr., Menston, Yorkshire: The Scolar Press, 1971), 69.

${ }^{59}$ Wright, Passions, 234.
} 
made by travelling there than those who had never sailed westward. Similarly, Stanney suggested, Catholics ought to believe the claims of those who had actually practiced a penitent lifestyle. ${ }^{60}$

Stanney's words made the consolation of penance sound like spiritual sustenance, much like writers who lauded the benefits of the eucharist. Stanney pointed to King David, who sought penance, wearing a hair shirt and eating ashes. David took this course, Stanney posited, seeking joy and consolation of the soul. God loved his servants who fasted and subjected themselves to penance. He rewarded their efforts in heaven, but also on earth, Stanney claimed, making penance "a sweet food and pleasant meat, which maketh them fat and strong." ${ }^{\prime 61}$

Penance could also bring believers closer to Christ because the penitent Catholic imitated Christ's example. Christ led a life of austerity, showing moderation in food, drink, and apparel. In his forty days in the wilderness, he willingly fasted, thirsted, and deprived himself of comfort. At his crucifixion, he accepted pain not as a punishment to his body but for a greater spiritual good. Christ revealed "the way," ${ }^{2}$ which was a journey to be taken, not a destination. Instead of needing a priest to perform the sacrament of penance, all of life could become ritualized, penitential behavior in imitation of Christ rather than subsumed under "Troubled or . . Affrighted" consciences. English Catholics need only adopt new understandings of the functions of penitence separate from, but related to, the familiar form of the sacrament and incorporate them into all aspects of life.

Although martyrdom was the most extreme form of imitatio Christi, penance could forge links between English Catholics and crucified Christ as well. A poem or carol, Death at the Oxford Assizes, implored Catholics to suffer as Christ suffered by performing penance for sins so that they could obtain salvation. The author, the martyr Richard Gwynne (or White), coaxed:

From Jesu's cradle to His Cross,

His life was naught but penance;

Just it is for us to walk in His footsteps

To gain eternal life

Let us do our penance whiles we live

We shall find him a merciful God;

He will call us, we shall be judged

And then we shall obtain our reward. ${ }^{63}$

\footnotetext{
${ }^{60}$ Stanney, A treatise, $50-53$.

${ }^{61}$ Stanney, A treatise, $50-52$.

${ }^{62}$ Stanney, A treatise, $49-53$.

${ }^{63}$ Poem probably written between 1577-84. Llanover MS, Welsh MS, 23, Ph.2954, 1:255 quoted in Pollen, Unpublished Documents, 97.
} 
Here again, an author encouraged penance as a lifestyle, rather than an occasional ritual, to obtain the reward of salvation.

Stanney and Wright utilized language of the crucifixion to persuade their readers to do penance for their sins and bond with Christ. Man's sinful desires and pleasures offended and displeased God, Stanney chastised. Therefore, he coaxed, "let us henceforth crucify this naughty man of ours, that Jesus Christ our Savior may live in us . . . let us therefore humble ourselves to death, even of the Cross: let us mortify our flesh with great fervor, let us chastise it with abstinence and severe penance." ${ }^{164}$ Life was "warfare upon earth," according to Wright, for the good Christian. The goal was to crucify a sinful nature, refining it in Christ's image ${ }^{65}$ Wright alluded to some of the crucifixion's most powerful symbols - Christ's crown of thorns and the five wounds-when discussing the penance that readers should perform. ${ }^{66}$

English Catholics needed to bond with Christ. By using these prayers of selfexamination, judgment, and penance, English Catholics enjoyed a new opportunity to identify with Christ through equating their individual redemption with Christ's achievement of universal redemption for humankind on the day of crucifixion. In pre-reform England, believers typically achieved this closeness through the sacrament of the altar, to which English Catholics no longer had reliable access. They could compensate by substituting and altering their understandings of other traditional religious practices such as penance to create new avenues to experience Christ.

\section{English Catholics Adopting a Penitent Lifestyle}

Despite these authors' persuasive advertisements of the benefits of selfexamination, self-judgment, and self-imposition of penance, would English Catholics buy into this re-conceptualization of penance? Evidence of lay adoption of such practices is rare. Self-examinations and self-judgments were personal matters. They would not likely be discussed in detail in letters between Catholics. The scant number of Catholic diaries of this period occasionally includes comments regarding examinations of conscience, but they do not go into sufficient detail to allow us to see if these authors' specific prescriptions have been adopted as part of this private ritual. What the evidence indicates is that English Catholics felt they needed to soothe their troubled and affrighted consciences and that English Catholics were

\footnotetext{
${ }^{64}$ Stanney, A treatise, 7; For further example, see Wright, Passions, 319-20, who instructed readers to crucify their sins so that they might follow the path of virtue.

${ }^{65}$ Wright, Passions, 91-92.

${ }^{66}$ Wright, Passions, 153.
} 
searching for alternative means to reap the benefits provided by the church and its sacraments and to renew closeness with God. One-on-one contrition, confession, and satisfaction before God himself could achieve these goals in the absence of the sacrament of penance.

The conclusion that some lay Catholics adopted such practices is strengthened by the rare piece of evidence such as the lay-authored prayer with which this article began. Many Catholics, the author bemoaned, had no one to care for their souls. In priests' absence, God stepped forward to care for the believer's soul. For this layperson, God revealed the supplicant's sins and the proper atonement due for them just as the clerical authors suggested. God personally guided the believer back to the road of salvation.

While it is impossible to estimate the size of the audience exposed to books and ideas advocating self-examination, judgment, and penance, we do have evidence that such books were circulating and that Catholics of varying ranks encountered them. Inventories of Catholic books seized by Protestant authorities include such books. One such seizure appears to have included copies of both Stanney's A treatise of penance and Wright's Passions of the Mind.$^{67}$ Extant inventories of the private libraries of Catholics also contain such works. ${ }^{68}$ Missionary priests sent letters requesting that such books in the vernacular be sent to the isle from the Continent. ${ }^{69}$ Additionally, authors strove to make their advice accessible to a wide audience of laypersons, not just erudite individuals of nobility and gentry rank. Radford, for example, encouraged the "unlearned" to read his work or have others read it to him, emphasizing how he had used plain words and accommodated himself to "the plain man's understanding." ${ }^{, 70}$ This was no idle hope. Catholics below the rank of yeoman were arrested carrying pastoral works of this type. ${ }^{71}$

Moreover, we have confirmation that English Catholics were performing penance, sometimes of the extreme variety. As might be expected, English clerics performed penance. They could confess themselves or one another and then seek absolution. Some clerics, however, adopted lifestyles of severe

\footnotetext{
${ }^{67}$ For examples, see BL, Lansdowne MS 153, ff. 67, 70; SP Dom 12/154/75, 14/7/89; Public Record Office, Kew, State Papers Scotland 52/49/31a.

${ }^{68}$ For example, see Selections from the Household Books of Lord William Howard of Naworth Castle (Durham: Surtees Society, LXVIII, 1878), 1xi, 257, 363.

${ }^{69}$ William Forbes-Leith, Memoirs of the Scottish Catholics during the Seventeenth and Eighteenth Centuries, selected from hitherto unedited manuscripts (London: Longmans, Green, 1909), 161-62, 208-9.

${ }^{70}$ Radford, A Directorie, A3. See also Stanney, 310-11, for further example of simplified didactic messages.

${ }^{71}$ See Nancy Pollard Brown, "Paperchase: The Dissemination of Catholic Texts in Elizabethan England," in English Manuscript Studies 1100-1700, vol. I, eds. Peter Beal and Jeremy Griffiths (Oxford: Basil Blackwell, 1989), 120-43; McClain, Lest We Be Damned, 49-54; Alexandra Walsham, Providence in Early Modern England (Oxford: Oxford University Press, 2001), 6, $32-35$.
} 
penance and often did so publicly, serving as powerful advertisements of penance to other Catholics. In 1591, for example, Protestant authorities executed the priest Montford Scot at the end of Fetter Lane in the Fleet Street area of London. During his imprisonment, Scot reportedly spent many hours daily praying upon his knees on the hard floors of his prison cell causing his knees to become rough and callused. When Scot was stripped prior to his death, one observer reportedly shouted, "I should be glad to see any one of our ministers with knees as much hardened by constant prayer as we see this man's are." Scot also fasted during his incarceration and grew thin waiting for his day of execution. Scot died alongside another priest, George Beesley, whom jailers had tortured and whom onlookers described as "a living skeleton of a man." A bystander, taken aback by the appearance of the two priests - one a penitent and one a victim of torture - allegedly called out in the crowd, "Is this treason? I came to see traitors and have seen saints." Protestant authorities arrested the catcaller and threw him in prison. ${ }^{72}$

Public evidence of penance could powerfully move lay sentiment and perhaps encourage private penitence. If a priest, whose sins were presumably few, needed to perform penance, then perhaps lay Catholics, whose sins were presumably greater, should consider adopting the practice. Furthermore, if such men felt that Catholicism merited imprisonment and self-imposed austerity, perhaps it was worthwhile to remain faithful to the old religion.

Some lay Catholics also performed penance, some even making penance a lifestyle rather than an isolated event, just as authors counseled. When Protestant authorities captured William Goodwyn and Brigett Palmer in 1587, they discovered a trove of Catholic papers and objects. Included in the inventory of absolutions, indulgences, pictures, and rosaries, they record a "whip of five cords." Each cord had a brass spur attached at the end. ${ }^{73}$ Goodwyn and Palmer evidently lived their daily lives gravely concerned over the eventual fate of their souls. They collected absolutions and indulgences, the church's forgiveness for sins. They prayed the rosary, another tool to garner remission of sins. Either one or both practiced flagellation with the whip, a severe form of self-imposed penance to repudiate sin and provide comfort.

Lay Catholics performed penance in jails, both in groups or individually, beneath the noses of Protestant authority, just as the priests Montford Scot and Robert Simpson had done. ${ }^{74}$ For example, small groups of devout Catholic prisoners performed penance and met for communal religious

\footnotetext{
${ }^{72}$ Edwin H. Burton, London Streets \& Catholic Memories (London: Burns, Oates \& Washbourne Ltd., 1925), 33. See also BL, Lansdowne MS 350, f. 12.

${ }^{73}$ SP Dom $12 / 206 / 53$. Indulgences were particularly popular in England according to Thayer, Penitence, 176.

${ }^{74}$ McGrath, "Apostate priests," 69.
} 
exercises within the Yorkshire jails. ${ }^{75}$ Some, such as a Mr. Sykes, lay on the cold floors of their cells for extended periods or slept upon boards in their cells. $^{76}$ Some fasted. Others wore hair shirts or knotted cords around their waists. ${ }^{77}$ John Gibson, a tailor, for example, secretly wore a hair shirt under his clothing while he was imprisoned for seven years before his death some time between 1585 and $1587 .^{78}$

Protestant jailers knew of such activities and even mocked them. In 1626, the provost marshal of Middlesex, John Tendring, suggested to the House of Commons that since Catholic prisoners "use whipping and fasting to merit heaven," the prisons should benefit from their austerity. Catholic prisoners were often unable to pay their jail fees, Tendring observed. If fasting and hardship were so valued by Catholics, why not make use of these values to cut prison expenses and discipline the prisoners? ${ }^{79}$ Penance could be used to advance multiple agendas.

\section{A New Voice in Larger Debates on Penance in Reformation EUROPE}

Differing understandings of penance constituted one of the major battlefields of the Reformation era. Tentler comments that at the same time that Continental writers upheld traditional understandings of the sacrament of penance, Protestants considered the "destruction" of sacramental penance to be a "primary and essential goal." $"$ "The pivotal issue of how and under what circumstances God delivered saving grace was at the crux of this conflict. ${ }^{81}$ The differences between what was suggested by the authors of the English pastoral texts discussed above and what was advocated by the pre-reform English church, post-Tridentine Continental authors, and English Protestants reveal that these English Catholic prescriptions are important and unexplored contributions to European-wide debates on confession and penance and how believers accrued God's salvific grace. For example, exhortations to examine

\footnotetext{
${ }^{75}$ Aveling, "Catholic Households in Yorkshire, 1580-1603," Northern History 16 (1980): 89-90.

${ }^{76}$ John Morris, ed., The Troubles of Our Catholic Forefathers Related by Themselves, 3 vols. (London: Burns \& Oates, 1877), 3:40.

${ }^{77}$ Morris, The Troubles, 3:38; Stanney, A treatise, 236-44.

${ }^{78}$ Stonyhurst MS, "Notes by a Prisoner in Ousebridge, Kidcote," printed in Morris, The Troubles, 3:322.

${ }^{79}$ SP Dom 16/22/111.

${ }^{80}$ Tentler, Sin and Confession, 369. See also Thayer, Penitence, 142-43, who contends that all major Protestant reformers abhorred sacramental penance, seeking not to reform abuses but to challenge the very understanding of the rituals and benefits associated with confession and penance.

${ }^{81}$ Protestant reformers devalued penance as a sacrament, alleging it did not pass the test of sola scriptura. Protestants did not agree, however, on what should replace sacramental penance to console and discipline Christians. See Tentler, Sin and Confession, 349-50.
} 
one's conscience can be found in many spiritual guides of the period, not just in English Catholic ones. Morning and evening examinations of conscience had frequently been recommended by the pre-reform English church and by postreform authors, both Catholic and Protestant. The difference lay in the benefits each group attributed to such examinations and what other activities, such as confession to or absolution by a priest, they assumed would follow such private examinations.

English Catholic prescriptions also differ from recommendations regarding penance by Catholic authors on the Continent following the Council of Trent. The post-Tridentine Roman Church made little accommodation to the restrictive realities of Catholic worship in England. Many post-reform English Catholic prayer books written during Elizabeth's reign still assume a priest will be physically present to perform the sacrament of penance. The most popular prayer book of the period, Vaux's Catechism, included instructions for confession. As an exile living on the continent in 1567, Lawrence Vaux had little experience with the daily challenges of practicing Catholicism in Protestant England. Vaux upheld the Council of Trent's insistence upon sacramental penance. A priest must be present to hear confession while performing the traditional sacrament despite the obvious impracticality of such a tenet. ${ }^{82}$

The authors who attempted to provide pastoral care to the English Catholic laity did not wish to contradict directly the Roman Church's teachings on this point. They were often selective, however, about which of the Council of Trent's mandates they chose to promote. Crowther and Vincent, for example, advertised that the Council of Trent supported the type of self-examination of conscience which these authors advised. The Decrees of the Council commanded "every Christian 'to examine himself seriously and to sound the deepest secrets, the most hidden folds, the darkest corner of his soul and conscience." The Council, however, assumed that Catholics would enjoy regular access to priests and the sacrament of confession and penance. The Council's enjoinment, therefore, was intended to encourage introspection prior to confession before a priest. ${ }^{83}$ The Council did not advocate selfjudgment or the self-imposition of penance as Crowther and Vincent would.

\footnotetext{
${ }^{82}$ Lawrence Vaux, A catechisme or a Christian doctrine necessarie for children \& the ignorant people (Liège, 1583 ed.), aiii. Although some Catholic commentators criticized Vaux's insistence on the continuation of late medieval practices, it is Vaux's views on penance with which lay English Catholics would have been most familiar due to the wide circulation of his catechism in the first decades of Elizabeth's reign. First printed in 1567, it was reprinted in 1574, 1583, 1599, and 1605 and circulated throughout England.

${ }^{83}$ The Council made this commandment to help Christians avoid receiving absolution from an incomplete confession (that is, holding back information on sins committed), which was considered sacrilege.
} 
On its own, the Council's self-examination would not be intended to accrue the same benefits toward salvation as Crowther and Vincent's. ${ }^{84}$

Post-Tridentine Catholic prayer books translated into English but written on the Continent by non-English authors during this period also advocated lay examinations of conscience, however without self-judgment and selfimposition of penance. They also insisted upon a priest's physical presence for confession and absolution. The Italian Gasparo Loarte's instructions for morning and evening examination of conscience, printed in English in 1613, for example, included a thanksgiving for God's blessings; a request for God's, Mary's, saints', and angels' protection and aid; a consideration of what sins have been committed; a craving for pardon for those sins; and the intention to avoid such sins in the future "with a purpose to confess that which we may have already transgressed in" to a priest. $^{85}$

Although Loarte asked readers to recite prayers such as the Pater noster, these prayers were not intended as acts of penance as they were in the books authored by English Catholics discussed above. Instead they were suggested as offerings to God on the behalf of others' souls, both living and dead. Notably absent were exhortations similar to those made by many post-reform English authors for readers to pass harsh judgment upon themselves.

The Spanish Jesuit Francis Borgia, the third General of the Society of Jesus, issued similar instructions for examinations of conscience without selfjudgment or self-imposition of penance. Borgia suggested no Pater nosters, Ave Marias, or any type of penance for the sins that a reader might identify in himself. ${ }^{86}$ Borgia clearly did not intend for his readers to judge themselves and risk usurping the proper functions of priests. In his directions for the sacrament of penance, he asked readers to take care in choosing a "virtuous, prudent, and expert priest." The priest alone would judge, absolve, and issue penance which the reader should lose no time in performing. ${ }^{87}$

In the face of Protestant challenges to the role of the clergy, it was crucial for these continental Catholic writers to preserve the chain of authority within the Roman Church. Through apostolic succession, priests were channels to God's grace. Through the sacraments and rituals of the church, priests mediated for

\footnotetext{
${ }^{84}$ Crowther and Vincent, Dayly Exercise, 40, quoting session 14, chapter 5 of the Decrees of the Council of Trent.

${ }^{85}$ Gasparo Loarte, Instructions and Advertisements How to Meditate upon the misteries of the Rosarie of the most holy Virgin Mary, trans. anonymous (1613; reprint, Menston, Yorkshire: The Scolar Press, 1970), 240-42. See also Luca Pinelli, The Virgin Marie's Life, Faithfully Gathered Out of Auncient \& Holie Fathers, trans. Richard Gibbons (Douai: Laurens Kellam, 1604), 96-99.

${ }^{86}$ St. Francis Borgia, The Practice of Christian Workes (1620; repr., Menston, Yorkshire: Scolar Press, 1970), 138-40. Although this work was originally published in Spanish, decades earlier, it was not translated into English until 1620.

${ }^{87}$ Borgia, The Practice, 141-51, 261, particularly 146. See also MacCulloch, The Reformation, 411-13.
} 
laypersons as Christ's authorized representatives on earth. There was little creativity shown in interpreting the priests' role, as some English priests and writers chose to do.

Reformers on the Continent and in England critiqued penance on many grounds. Both Luther and Calvin criticized sacramental confession as burdensome. The salvation promised was impossible to achieve. It caused individuals to be tormented with the hopelessness of identifying and confessing every sin committed under pain of damnation. ${ }^{88}$ Instead, Luther argued that Christ's sacrifice on the cross achieved forgiveness of sins for humankind once and for all.

This is not to suggest that Protestant reformers considered conscience, contrition, and sinfulness unimportant. Instead, reformers asked believers to focus upon and experience contrition for their own general, inherent sinfulness rather than becoming preoccupied with expiating individual sins. In this way, sinners might amend their entire lives. ${ }^{89}$

Although there existed some variety among English Protestant mentalities and attitudes toward confession and penance, the most widespread type of English Protestant confession was a formal, general confession of sin made publicly. ${ }^{90}$ Rather than having an individual chronicle each sin privately before a priest, the entire congregation simultaneously recited:

Almighty God, Father of Our Lord Jesus Christ, Maker of all things, Judge of all men, We acknowledge and bewail Our manifold sins and wickedness, Which we from time to time most grievously have committed in thought, word, and deed against thy divine Majesty, provoking most justly thy wrath and indignation against us. We do earnestly repent, and are heartily sorry for these our misdoings. The remembrance of them is grievous unto us. The burden of them is intolerable. Have mercy upon us, Have mercy upon us most merciful Father; For thy Son, our Lord, Jesus Christ's sake, forgive us all that is past, and grant that we may ever hereafter serve and please thee in newness of life, to the honor and glory of thy name, through Jesus Christ our Lord. Amen. ${ }^{91}$

\footnotetext{
${ }^{88}$ The Oxford Encyclopedia of the Reformation, 1:401-3; Jean Delumeau, L'aveu et le pardon: Les difficultés de la confession, XIIIe-XVIIIe siècle (Paris: Fayard, 1990); Thayer, Penitence, 142 43, 150-52; Euan Cameron, The European Reformation (Oxford: Oxford University Press, 1991), 305-7; MacCulloch, The Reformation, 129.

${ }^{89}$ Myers, Poor Sinning Folk, 63-72. Reformers also ensured specific sins were investigated and punished but through alternative means to sacramental confession, such as through Calvinistinfluenced civic magistrates/consistory courts. MacCulloch, The Reformation, 593-95.

${ }^{90}$ For alternative views on sin, guilt, and despair among English Protestants, see John Stachniewski, The Persecutory Imagination: English Puritanism and the Literature of Religious Despair (New York: Oxford University Press, 1991); Patrick Collinson, The Elizabethan Puritan Movement (Berkeley: University of California Press, 1967), 346-71.

${ }^{91}$ For form of general confession used in Church of England after 1559, see Bernard Wigan, ed., The Liturgy in English (London: Oxford University Press, 1962), 6-7.
} 
There was no intimate examination of conscience preceding this confession. The cleric did not ask detailed questions to any individual or the group as a whole about their sexual activities, drinking habits, vanity, gossiping, or uncharitable thoughts as seen in Stanney's and Wright's directives. Because every person, as a descendant of Adam, was guilty of all sin, the reformers taught that no individual need examine his own conscience to ferret out and confess each $\sin$ as a prerequisite to salvation.

Nor should reformers' rejection of sacramental penance be seen to imply that individuals no longer consulted the clergy privately on matters of conscience. They certainly did, but now such meetings served a pastoral purpose rather than a sacramental one. ${ }^{92}$ Luther, for example, denounced mandatory, sacramental confession yet continued to insist that confession was necessary for an individual's consolation. Calvin was reluctantly willing to hear parishioners' confessions but used such discussions as opportunities to explain that his counsel was not a sacrament nor should it be. ${ }^{93}$

In addition to the general public confession above, non-sacramental private auricular confessions remained optional in the Church of England. ${ }^{94}$ As Keith Thomas, John Bossy, and Thomas Tentler have noted, Protestant churchmen quickly realized that the Catholic confessional had served an important purpose: the enforcement of religious and social morality. The Book of Common Prayer accordingly commanded the celebrant at the Lord's Supper to encourage all parishioners who were troubled to come to him privately for comfort and counsel. ${ }^{95}$ This practice, however, differed in several significant ways from the Catholic confession and penance described above. Parishioners were not compelled to seek out the cleric. The word "confession" was not used nor was the cleric to examine or absolve the parishioner. No penance was to be assigned to remit the temporal punishment of any sin. The cleric was to be a counselor to heal the parishioner's guilty conscience rather than a mediator who provided access to salvation. ${ }^{96}$

\footnotetext{
${ }^{92}$ Tentler, Sin and Confession, 349-62; Thayer, Penitence, 143.

${ }^{93}$ Luther's Small Catechism, The Augsburg Confession, and Philip Melanchthon's Loci Communes all continue to allow private auricular confession, however in non-mandatory, nonsacramental form. See The Oxford Encyclopedia of the Reformation, 1:401-2. See Thayer's excellent description of Luther's views on confession and penance in Penitence, chapter 5, and Tentler, Sin and Confession, 50.

${ }^{94}$ Henry VIII's Ten Articles (1536) and Six Articles (1539) had both endorsed private auricular confession, but the prayer books adopted by Edward VI and Elizabeth I only allowed it. The Oxford Encyclopedia of the Reformation, 1:402.

${ }^{95}$ Keith Thomas, Religion and the Decline of Magic (New York: Charles Scribner's Sons, 1971), 154-58. Tentler, Sin and Confession, xiii; John Bossy, "The Social History of Confession on the Eve of the Reformation," Transactions of the Royal Historical Society, 5th series, 25 (1975): $21-38$.

${ }^{96}$ Kenneth L. Parker, "Richard Greenham's 'spiritual physicke': The Comfort of Afflicted Consciences in Elizabethan Pastoral Care," in Penitence, ed. Lualdi and Thayer, 71-83. For
} 
Reformers also questioned the necessity to salvation of making satisfaction for sin. Protestants reached heaven through their faith in the sufficiency of Christ's sacrifice, not through expiating the punishment due for their sins through penance or other good works. For example, following the general form of confession above, the cleric pronounced an assurance of absolution over all the parishioners simultaneously. God would have mercy upon the believer and "pardon and deliver you from all your sins, confirm and strengthen you in all goodness, and bring you to everlasting life." ${ }^{.97}$ No penance was required because a believer's faith in God's immeasurable grace was sufficient to earn salvation. ${ }^{98}$ Penance could be appropriate but only if done as a sign of sincerity and justification rather than to make satisfaction for sins. ${ }^{99}$

By contrasting these differing views on confession and penance, it becomes evident that English Catholic accommodations to the realities of practicing Catholicism illegally in a Protestant country provide an alternative to historians' and theologians' traditional understandings of Catholic and Protestant debates on this issue. Penance was at the heart of Reformation-era conflicts. The post-Tridentine Roman Church upheld the pre-reform sacrament of penance performed by one's parish priest for forgiveness of sins to help save one's soul. A priest served as judge, examining the penitent and listening to the accused testify against himself. The priest, as God's representative on earth and vested with full authority to forgive sins, absolved the believer and passed a sentence of penance upon the sinner. English Catholic authors of the pastoral works discussed here fully supported

more on Greenham, see Theodore Dwight Bozeman, The Precisianist Strain: Disciplinary Religion \& Antinomian Backlash in Puritanism to 1638 (Chapel Hill: University of North Carolina Press for the Omohundro Institute of Early American History and Culture, 2004), chapters 4 and 5.

${ }^{97}$ See form of absolution in Wigan, Liturgy, 7.

${ }^{98} \mathrm{~A}$ majority of reformers valued penance but not as a sacrament and not to achieve forgiveness of sin. Instead, they understood it in light of being truly repentant or contrite for one's misdoings. True guilt and contrition were seen as evidence of God's saving grace rather than as a means to that grace. Once the believer's heart buckled under his guilt and remorse, Protestant clerics consoled him that this was proof of his complete and wholly unmerited forgiveness from Christ. Moreover, Protestant reformers decried the asceticism and self-mortification of many Catholic penitents. Rather than viewing self-denial as holy, Protestants believed that financial security and honor inclined the believer to do even more good in the world and was evidence of God's special favor. William Hunt, The Puritan Moment: The Coming of Revolution in an English County (Cambridge: Harvard University Press, 1983), 120-21, 126.

${ }^{99}$ See Martin Luther, Three Treatises, 294, 308. John Calvin, Institutes of the Christian Religion, book 3 , chapters $3-10$, suggests that properly performed penance consists of changes in lifestyle, revitalization of the spirit, and even mortification of the flesh, so long as such mortification is done prudently and not misguidedly or zealously. In general, however, reformers encouraged internal versus external acts of penance. Both in The Oxford Encyclopedia of the Reformation, $3: 243$. 
this interpretation of the sacrament of penance. Some of these authors counseled, however, that in the absence of its availability, the believer might bypass the priest and examine himself, confess directly to God, and impose judgment and penance upon himself as directed by God. In contrast, the Protestant Church of England denied the validity of sacramental confession and penance altogether. English Protestants, like the English Catholics, claimed that God himself forgave sins without a priest's intercession. Unlike the English Catholics, however, they devalued the priest's role in confession. And unlike the English Catholics who imposed penance upon themselves to atone for their sins, the Church of England taught that no such penance was necessary to earn salvation. Self-evaluation, criticism, and repentance were encouraged and, indeed, expected among English Protestants, but such actions were not understood as producing salvific grace in the same way as they were for Catholics. ${ }^{100}$

\section{CONCLUSION}

The mid-seventeenth-century prayer with which this article began conveyed the reality of the English Catholic situation: many lay Catholics had "troubled consciences" and "affrighted" souls. Also contained in this prayer, however, are hints as to how English Catholics could learn to comfort themselves in their adversity. The anonymous author continued:

Oh hear me for thy Son Jesus's sake. That it may please thee to recompense all those whom thou hast raised to be Instruments of any good to me: such as have taken care of my soul and instructed me in the way to Heaven; such as have counseled me when I have gone astray, supplied me in my wants, comforted me in my heaviness and have had that high Charity for me, as to reprove me when I have sinned. ${ }^{101}$

English Catholics secretly culled religious knowledge and solace from whatever sources were still available: books, peripatetic priests, lay friends, neighbors, and family members. The author asked God to bless those who had been "Instruments of any good" to him. Significantly, the word "priest" or "cleric" never appears in this prayer. ${ }^{102}$

The authors of the texts discussed above touted the ability of God to deliver the benefits of the sacraments in the absence of priests. What the Roman

\footnotetext{
${ }^{100}$ See Bozeman, The Precisianist Strain, chapters 1, 4, and 5.

${ }^{101}$ BL, Sloane MS 4035, f. 12.

${ }^{102}$ This runs directly counter to the Council of Trent's attempt to enforce lay Catholic loyalty to one priest and one parish, thereby limiting a layperson's exposure to a multiplicity of religious influences.
} 
Church had hitherto allowed only in cases of extreme necessity became the day-to-day rule in England. By examining their own consciences, judging themselves, and exacting penance upon themselves, some authors told English Catholics that they would obtain many of the same results as sacramental confession and penance: remission of sin, salvation of the soul, and a closer, comforting relationship with Christ. It would have been difficult for a lay reader to discern much difference between benefits associated with the traditional sacrament and profits advertised by these authors for the alternatives they prescribed. Perhaps this confusion was what the priests intended. They wanted to encourage the actual sacrament whenever possible, but when not possible, the authors wanted English Catholics to protect their souls as best they could. They wanted to comfort English Catholics. Evidence suggests that some English Catholics adopted a penitential lifestyle, as these pastoral authors prescribed.

On a larger scale, this investigation into penance is part of a more detailed examination into how ordinary Catholics transformed their understandings of pious practices following the ideological clashes of the Reformation era. This analysis suggests ways in which ordinary lay and clerical Catholics in the British Isles - though seemingly isolated from their counterparts in Rome and on the continent-subtly reshaped what it meant to be a Catholic. Despite characterizations of the Reformation-era Roman Church as doctrinal, orthodox, and traditional, the Church remained, as it always had been, defined by the interplay between the rules handed down by the Church, the efforts of pastoral clergy, and the reception of these rules by ordinary believers. There were believers who, in the case of English Catholics, were intensely devoted to the Roman Church and its hierarchy, and yet felt free to ask for help directly from God, asking God "to hear the Groans and Cries of all that are afflicted either outwardly or inwardly in Body or Soul: especially such who being oppressed for conscience sake have no place to fly unto nor no man careth for their souls," trusting that they could make such a request resting comfortably within the bounds of the Roman Church. 